\section{(2) OPEN ACCESS}

\title{
Low-dose naltrexone as a treatment for chronic fatigue syndrome
}

\author{
Monica Jane Bolton 다, ${ }^{1}$ Bryan Paul Chapman, ${ }^{2}$ Harm Van Marwijk ${ }^{3}$
}

\begin{abstract}
${ }^{1}$ Patient, Manchester, UK ${ }^{2}$ Patient, West Sussex, UK ${ }^{3}$ Department of Primary Care and Public Health, Brighton and Sussex Medical School, Brighton, UK
\end{abstract}

Correspondence to Professor Harm Van Marwijk; H.vanMarwijk@bsms.ac.uk

Accepted 13 October 2019

Check for updates

(C) BMJ Publishing Group Limited 2020. Re-use permitted under CC BY-NC. No commercial re-use. See rights and permissions. Published by BMJ.

\section{To cite: Bolton MJ}

Chapman BP,

Van Marwijk H. BMJ Case

Rep 2020;13:e232502.

doi:10.1136/bcr-2019-

232502

\section{SUMMARY}

Naltrexone is used as an off-label treatment in low doses for several chronic immune-modulated disorders in many countries. Although only small-scale clinical trials have been performed, these suggest efficacy in several diseases including Crohn's disease, fibromyalgia and Gulf War Illness. Despite numerous internet reports of response to low-dose naltrexone (LDN), no clinical trials exist in people with chronic fatigue syndrome. This condition is characterised by chronic profound fatigue, postexertional malaise, pain and autonomic and neurocognitive disturbances. This series of three case reports compiled by people with long-term ill-health due to chronic fatigue syndrome shows the range of responses they observed when taking LDN, from life changing to a reduction in some symptoms only. Treatment doses ranged from 4 to $12 \mathrm{mg}$. Clinical trials may be warranted to explore the potential use of naltrexone in people with these debilitating illnesses which currently have no licensed treatments available.

\section{BACKGROUND}

Chronic fatigue syndrome and myalgic encephalomyelitis are chronic multisystem disorders characterised by profound fatigue and postexertional malaise with multiple other symptoms varying among individuals, including widespread pain, immune dysfunction and autonomic and neurocognitive symptoms. ${ }^{1}$ The annual incidence is around $15-26$ per 100000 persons, ${ }^{23}$ with a prevalence between $0.2 \%$ and $0.4 \%,{ }^{45}$ depending on the exact definition used and the country of study. The level of disability is greater than for most other chronic illnesses, and full recovery is rare. ${ }^{6-8}$ Much is unknown about the illness and even the names ascribed are controversial. ${ }^{1}$

There is a systematic lack of funding of research and specialist services for people with these conditions. ${ }^{910}$ Despite specialists, particularly in the USA, using a range of drugs in treatment, ${ }^{11} 12$ very few of these have been subjected to clinical trials, and the outcomes of the few that have been done have often been inconclusive. ${ }^{13} 14$ Reasons for failure to reach conclusions include difficulties in clinical trial design such as trials of short duration and small sample sizes; a lack of a single best clinical case definition and of a simple diagnostic marker ${ }^{1}$ and difficulties in measuring outcomes (such as no way of measuring fatigue objectively). Many of these issues are associated with poor funding opportunities. ${ }^{15}$
Naltrexone is a safe synthetic antiopioid with widespread action at opioid and non-opioid receptors. ${ }^{16}$ It is currently licensed for treatments of alcoholism and opioid addiction at $50 \mathrm{mg}$. At lower doses, 3-4.5 mg, it appears to work as an immune modulator, ${ }^{17}$ and can also suppress tumour growth. ${ }^{1819}$ This usage is commonly described as low-dose naltrexone (LDN). ${ }^{20}$ Small-scale clinical trials of LDN in multiple sclerosis, HIV, fibromyalgia, Gulf War Illness and Crohn's disease have shown proof-of-concept efficacy and/or low toxicity. ${ }^{21-28}$ Recent before-and-after cohort studies of patients with Crohn's disease and rheumatoid arthritis in Norway showed reductions in prescriptions for disease-modifying medications after starting LDN..$^{29} 30$ We know of no clinical trials of naltrexone in patients with chronic fatigue syndrome or myalgic encephalomyelitis, although some patients report benefits. ${ }^{31}$ We present a series of three case reports of this treatment as a prelude, we hope, to future clinical trials. The reports were compiled by those people whose case histories are described, two of whom are coauthors, using historic diaries and previous medical records, including any objective measures that were available.

\section{CASE PRESENTATION: CASE 1}

A white British female, now aged 63 (the first author), developed viral meningitis with accompanying vomiting leading to severe dehydration in 1988 when aged 33. She had previously been well and working as a general practitioner. Viral meningitis was diagnosed by lumbar puncture and again 6 weeks later on repeat hospital admission. She remained extremely unwell, being bed bound and unable to self-care, with profound weakness and fatigue, general malaise, light and sound sensitivity, repeated dizziness causing collapse, persistent anxiety and widespread pain. Although she improved slowly over the next 5 years, she was only able to return to work on a limited basis, still suffering headaches, fatigue, postexertional malaise and frequent migraine attacks characterised by vomiting and visual disturbances.

Following gastroenteritis in 1999, she again became bed bound and unable to self-care. Improvement was slower than the initial illness, and after 5 years she was still dependent on carers and used a motorised wheelchair when outside. She developed multiple food intolerances, shown on blood tests and confirmed by repeated withdrawals and reintroductions of intolerant foods. She showed a more 
dramatic response to wheat, even small amounts, characterised by nausea, severe headache, rapid heart beat and collapse within $10 \mathrm{~min}$ of consumption, followed by a week of reduced energy and absolute constipation.

\section{INVESTIGATIONS: CASE 1}

Extensive investigations were performed during several hospital admissions following the initial meningitis, including extensive screening for infections, brain scan and electroencephalogram. These were all normal, and she was diagnosed with chronic fatigue syndrome by the hospital clinician in 1989. This diagnosis was confirmed in 2001 and 2003 by a rheumatologist and a psychiatrist, respectively; in the latter case confirming the diagnosis by reference to the 1994 Centres for Disease Control criteria for chronic fatigue syndrome. ${ }^{32}$ In 2001, she was diagnosed by a clinical neuropsychologist as having cognitive impairments characteristic of damage from viral meningitis. Although her IQ was in the very superior range, she was unable to complete the timed Stroop Neuropsychological screening test (less than second centile) ${ }^{33}$; the trail making test was below the 25 th percentile $\mathrm{e}^{34}$ and the Ray complex figure was below the 25 th centile. ${ }^{35}$ These results showed respectively an inability to exclude irrelevant but superficially similar information, poor multitasking abilities and reduced visuospatial ability and memory. These results had improved only slightly by 2004, with further slight improvements by 2019; both the Ray complex figure and the Stroop test still scoring below the 25 th centile for her age and educational level although the trail making test is now around the 50th centile.

An MRI scan of the brain in 1998 was normal, and an antigliadin antibody test for coeliac disease was negative in 2002. In 2009, she was shown to be deficient in vitamin D (25-hydroxyvitamin $\mathrm{D}_{3}$ level of $22.7 \mathrm{nmol} / \mathrm{L}$, current guidelines suggest above $50 \mathrm{nmol} / \mathrm{L}$ is sufficient).

\section{TREATMENT: CASE 1}

She tried various alternative treatments with little improvement. She improved slightly while taking antibiotic combinations including phenoxymethylpenicillin and azithromycin for a year in 2006 but relapsed rapidly on stopping them. She was started on oral vitamin D supplementation in 2009 , although this did not improve her symptoms of fatigue. As she has had polymorphic light eruption since her midteens, she remains on colecalciferol 20000 IU every 2 weeks and now has normal vitamin D levels.

In 2010, she was prescribed LDN, initially at $1.5 \mathrm{mg}$, slowly increasing the dose over 2 years. She noticed slightly increased energy and reduced food intolerances while taking $4.5 \mathrm{mg} /$ day but needed to reduce the dose to $3 \mathrm{mg}$ due to increased headaches. Ten months later, she started increasing the dose again without recurrence of symptoms, and subsequent stepped dose increases coincided with further improvements in energy, mood and pain. At $9 \mathrm{mg}$, the frequent episodes of abdominal pain subsided, and she started eating a full diet, including wheat and dairy. Her prescribing doctor suggested experimenting to find the optimum dose of LDN, and after increasing to $7.5 \mathrm{mg}$ two times per day, she settled on $6 \mathrm{mg}$ two times per day, which she has taken for the past 7 years.

\section{OUTCOME AND FOLLOW-UP: CASE 1}

Now aged 63, 30 years after the initial meningitis, she currently has a normal quality of life with no signs of ill health, although energy levels can reduce slightly during infections, prolonged overexertion or excessive mental effort. Such reductions can be delayed up to 48 hours after the initial overstimulation, suggestive of continuing mild postexertional malaise. Symptoms such as poor sleep and excessive pain are absent. Up until starting LDN, she was in receipt of the UK Government's benefits of Disability Living Allowance at the higher rate for mobility (requiring the person to have severe walking difficulties) and middle rate for care (requiring frequent help during the day). These payments were reduced, and then finally stopped 3 years after starting LDN when it was clear she was stable and well, and could walk, and more recently, cycle, without problems. Prior to starting LDN, her intellectual and cognitive functioning was very limited. These abilities have returned apart from continuing cognitive impairments due to the meningitis.

\section{CASE PRESENTATION: CASE 2}

A previously well white female living in the USA, developed a sudden onset of ill health when 29 years old in 1989. Symptoms included profound fatigue and weakness, flu-like symptoms, postexertional malaise, cognitive impairment, nausea, widespread pain and sleep disturbance. Possible precipitating factors included possible viral infection, early pregnancy and exposure to ticks within 6 weeks of onset. She was diagnosed with chronic fatigue immune dysfunction syndrome by a neurologist after 2 years of ill health and this diagnosis, and/or myalgic encephalomyelitis has been reconfirmed several times since. During subsequent years, she continued with symptoms of postexertional neuroimmune exhaustion (as defined in the International Consensus Criteria for myalgic encephalomyelitis (2011)), ${ }^{36}$ pain, periodic muscle weakness, flu-like symptoms, orthostatic intolerance and unrefreshing sleep despite seeing many specialists.

\section{TREATMENT: CASE 2}

Many therapies have been tried, including antiviral agents for reactivated Epstein-Barr virus, with limited success.

She was prescribed LDN in 2014 when 54 years old. Due to known immune hypersensitivity (urticaria), the dose was started very low, at $0.25 \mathrm{mg} /$ day, and increased very slowly over 4 years to the present dose of $4 \mathrm{mg}$. Initially, her sleep was disturbed by vivid dreaming. At about 6 months, when on $1 \mathrm{mg} /$ day, she noticed improved sleep and lower pain levels, and these symptoms continued to improve as the naltrexone dosage was increased

\section{OUTCOME AND FOLLOW-UP: CASE 2}

Although pain and sleep issues continue, these are at a lower level than prior to starting naltrexone. Her sleep journal prior to starting LDN showed she awoke every $90 \mathrm{~min}$ through the night. Monitoring after starting LDN shows that although she may not sleep through, she does not have repeated awakenings. She no longer requires acupuncture for symptomatic pain relief. However, her functional level did not improve with LDN. Now aged 59, she also continues with other symptoms of myalgic encephalomyelitis including postexertional neuroimmune exhaustion, periodic muscle weakness, orthostatic intolerance, symptomatic sinus tachycardia, urticarial rashes and susceptibility to bacterial infections. Due to these, she takes ivabradine $2.5 \mathrm{mg}$ two times per day and cetirizine $10 \mathrm{mg} /$ day. Despite these continuing symptoms, she feels LDN is of sufficient benefit to continue long term.

\section{CASE PRESENTATION: CASE 3}

A white British male (the second author) sustained a head injury when 7 years old and was diagnosed with glandular fever when 
10 years old. He developed severe tonsillitis in 1996 when 14 years old. His symptoms gradually worsened and he became bedridden and unable to self-care, suffering profound fatigue, headaches, excessive day and night sleeping and light and sound sensitivity. He was diagnosed with chronic fatigue syndrome by a hospital paediatrician in 1997 . He gradually improved over the next 3 years with increased energy. By his mid-20s, he was able to work full time although with persistent tiredness and recurrent infections. He improved further by practising 'pacing', listening to body symptoms to control his activity and by changing jobs to one with flexible working hours, which he continues to this date. He continued to experience difficulty sleeping and recurrent colds, at least four per year, accompanied by energy dips and subsequent depression. He was diagnosed with nasal polyps, sinusitis and seasonal allergic rhinitis.

\section{TREATMENT: CASE 3}

In 2018 , when aged 37 , he started LDN, initially at $1 \mathrm{mg} /$ day, increasing to $4.5 \mathrm{mg}$, which he still takes. He had no side effects starting the drug.

\section{OUTCOME AND FOLLOW-UP: CASE 3}

He noticed an improved sleep pattern, and now has fewer colds which are no longer associated with an energy dip or subsequent depression. Retrospective scoring of depression using the Hospital Anxiety and Depression Scale ${ }^{37}$ suggests his average mood improved from 13 (11-21 signifies depression) to 7 (0-7 signifies no abnormality), his anxiety scores being normal throughout. His functional level improved from being mildmoderately limited on a daily basis $(60 \%-70 \%$ on a functional activity scale) to mild limitations $(80 \%-90 \%$ on a functional activity scale ${ }^{38}$ ). The improvements are sufficiently marked that he intends to continue LDN long term.

For the past 4 years, he has followed a gluten and wheatfree diet and has been vegan for the past 18 months, partly due to cheese causing increased nasal symptoms. He has not tried altering his diet after starting naltrexone.

\section{DISCUSSION}

Given the widespread use of LDN in many countries, and the numerous internet reports, it is somewhat surprising that this is the first medical series of case reports of the effect of its use in people with chronic fatigue syndrome and myalgic encephalomyelitis. The mechanism of action for naltrexone at low dose in this disease group is unknown. It is possibly due to rebound of endorphins following short-term suppression or to direct action suppressing inflammation induced by microglia. ${ }^{39-41}$ There have been no formal dosing studies of naltrexone at low dose in any disorder. Therefore, although the dose of 3-4.5 mg is established in clinical practice, some practitioners use $9 \mathrm{mg}$ (Klimas, personal communication, 2017) or higher ${ }^{42}$ in chronic fatigue syndrome. Causality and dosing need further study.

All case reports are limited by their lack of controlling for confounding factors and for possible placebo responses. Such factors can only be adequately controlled for within a randomised double-blind clinical trial. In the recent placebocontrolled, double-blind multicentre trial of rituximab in chronic fatigue syndrome, the placebo response rate was $35 \%{ }^{43}$ Alternative explanations for improvements in these cases could also be due to fluctuations in the underlying disease, which can appear as temporary improvements and occasionally the disease improves spontaneously. However, all three subjects had tried alternative treatments without the long-term effects that LDN has produced, which in cases 2 and 3 were specific to particular symptoms. Although case 1 had noticed periods of moderately

\section{Patient's perspective}

\section{Case 1}

For me, low-dose naltrexone was truly life changing. From being virtually house bound, always limited by a multitude of symptoms, pain and low energy, I found my life returning. Every treatment or therapy I had tried previously involved effortpacing myself, training myself, coping with symptoms. With lowdose naltrexone, the improvement just happened—I didn't have to try, I just got better. I went for walks and started cycling again. The first time I ate out when I was no longer limited by food allergies, I could select from the whole menu- the shock of all that choice! My husband commented I was no longer a shadow of a person but a genuine companion again. From being unable to string sentences together coherently for much of my adult life, I returned to university and gained a distinction in a Master of Research degree, when aged 62!

\section{Case 2}

After 25 years of living with the devastating effects of myalgic encephalomyelitis, I was struggling to cope with the limited options for symptom and pain management. Having had many bad reactions to medications, I was hesitant to try a medication that would affect my immune system so I started out at an extremely low dose and slowly increased dosage. While the dreaming was at times disturbing, the positive changes gave me a hope for improvement I had not had in many years. The subsequent improvements have led to a much higher quality of life and I would like to see this medication as an approved option for others in my situation.

\section{Case 3}

Since I was 14 (when I had my first chronic fatigue episode), whenever I have had any form of illness I have suffered from depressive episodes, including needing to withdraw socially and becoming very insular. This included the period prior to any illness, where I have felt run down or could tell a cold etc was forming. I started taking low-dose naltrexone when I was 37 and for the first time in 23 years, I have not had a depressive episode linked to colds or any other illness. Low-dose naltrexone has really helped improve my quality of life and also helped in social situations where I am not withdrawing and being insular like I had been previously.

\section{Learning points}

- Naltrexone at low dose may work as an immune modulator and small scale clinical trials in a range of conditions including fibromyalgia, Gulf War Illness and Crohn's disease have shown efficacy and low toxicity.

- Although no clinical trials have been carried out, anecdotal web reports, and these three case studies suggest low-dose naltrexone may be helpful in at least some patients with chronic fatigue syndrome and myalgic encephalomyelitis.

- Clinical trials of off-patent drugs are difficult to fund. The lack of mechanisms for funding and licensing such drugs is a political issue which needs urgently addressing to save healthcare systems from ever-escalating drug costs. 
improved health previously, these were limited in time, and her cognitive abilities had not previously improved. In addition, the initial improvements in symptoms with LDN were associated at each time point with an increase in dosage, and above $12 \mathrm{mg}$ there was no further improvement, suggestive of a typical graded dose-response curve.

Internet reports suggest side effects can be troublesome initially, particularly increased fatigue and headaches. ${ }^{44}$ Two double-blind, placebo-controlled studies in people with fibromyalgia found no difference in tolerability between LDN and placebo but an increased frequency of vivid dreams and headaches. ${ }^{27} 28$ Recent work in Norway has found that individuals may experience fewer side effects if starting naltrexone at $6 \mathrm{mg}$, even if the final dose taken is lower than this (personal communication Brian Haviland 2018).

Not everyone with chronic fatigue syndrome or myalgic encephalomyelitis responds to naltrexone, although the exact proportion or the characteristics of those who do respond are not known. The three cases described here, compiled by three patients taking the drug, are typical of the range of responses in those who do respond, from a partial response through to life-changing differences. We recognise we had similar rapid onsets of illness, prolonged illnesses with limitation of life and curtailment of careers over many years and similar immune hyper-reactivity to external stimuli. Despite these similarities, it is not known whether we are describing particular characteristics which would make response to LDN more likely. The first and third case studies described reductions in symptoms of anxiety and depression, respectively, which therefore might originate from reduced neuroinflammation. ${ }^{45}$

These case studies are presented in the hope they will lead to randomised clinical studies defining the role and dose of naltrexone in treating people with chronic fatigue syndrome and myalgic encephalomyelitis compared with usual care or placebo. However, as naltrexone is out of patent, funding for such studies is problematic, despite the drug itself being relatively cheap. Most large studies are funded by large pharmaceutical companies, and there is no incentive for them to continue research of drugs once they are off-patent. However, we intend to replicate the approach of pharmaceutical companies by designing any clinical studies with licensing requirements in mind and will seek advice from the Medicines and Healthcare Products Regulatory Agency to this end.

\section{Acknowledgements We thank the person whose case history is described as case 2 for writing her case history and patient perspective and for multiple helpful comments on this paper. We acknowledge the care of Dr J McCabe, the prescribing doctor for this patient. We thank those doctors who provided care for MB (case 1) over the past 30 years, particularly Dr T Gilhoolie for his use of slightly higher doses of naltrexone than is customary and the doctors of Clinic 158 for the care of $B C$ (case 3). \\ Contributors MJB and HVM conceived the case series. MJB contacted likely contributors and drafted the initial article. MJB, 'case 2' and BPC wrote their individual case histories for which they are guarantors. Case histories were edited by MJB and checked with prescribing doctors in each case. All authors commented on draft versions and approved the final version.}

Funding The authors have not declared a specific grant for this research from any funding agency in the public, commercial or not-for-profit sectors.

Competing interests None declared.

Patient consent for publication Obtained.

Provenance and peer review Not commissioned; externally peer reviewed.

Open access This is an open access article distributed in accordance with the Creative Commons Attribution Non Commercial (CC BY-NC 4.0) license, which permits others to distribute, remix, adapt, build upon this work non-commercially, and license their derivative works on different terms, provided the original work is properly cited and the use is non-commercial. See: http://creativecommons.org/ licenses/by-nc/4.0/.

\section{ORCID iD}

Monica Jane Bolton http://orcid.org/0000-0002-7972-1841

\section{REFERENCES}

1 Institute of Medicine. Beyond myalgic Encephalomyelitis/Chronic fatigue syndrome: redefining an illness, 2015. Available: https://www.iom.edu/Reports/2015/ME-CFS. aspx [Accessed 1 Jun 2015].

2 Bakken IJ, Tveito K, Gunnes N, et al. Two age peaks in the incidence of chronic fatigue syndrome/myalgic encephalomyelitis: a population-based registry study from Norway 2008-2012. BMC Med 2014;12:167.

3 Collin SM, Bakken IJ, Nazareth I, et al. Trends in the incidence of chronic fatigue syndrome and fibromyalgia in the UK, 2001-2013: a clinical practice research Datalink study. J R Soc Med 2017;110:231-44.

4 Jason LA, Richman JA, Rademaker AW, et al. A community-based study of chronic fatigue syndrome. Arch Intern Med 1999;159:2129-37.

5 Nacul LC, Lacerda EM, Pheby D, et al. Prevalence of myalgic Encephalomyelitis/ Chronic fatigue syndrome (ME/CFS) in three regions of England: a repeated crosssectional study in primary care. BMC Med 2011;9:91.

6 Cairns R, Hotopf M. A systematic review describing the prognosis of chronic fatigue syndrome. Occup Med 2005;55:20-31.

7 Nacul LC, Lacerda EM, Campion P, et al. The functional status and well being of people with myalgic Encephalomyelitis/Chronic fatigue syndrome and their carers. BMC Public Health 2011:11:402.

8 Falk Hvidberg M, Brinth LS, Olesen AV, et al. The health-related quality of life for patients with myalgic encephalomyelitis / chronic fatigue syndrome (ME/CFS). PLoS One 2015;10:e0132421

9 Radford G, Chowdhury S. Me/Cfs research funding an overview of activity by major institutional funders included on the dimensions database, 2016.

10 Action for ME. Ignorance, injustice and neglect. An investigation into NHS specialist service provision for people with ME/CFS. Bristol, 2012. Available: http://www. actionforme.org.uk/OneStopCMS/Core/CrawlerResourceServer.aspx? resource= f11e86c4-9ca3-4185-9934-e43f7e4b3bec

11 Kogelnik AM, Loomis K, Hoegh-Petersen M, et al. Use of valganciclovir in patients with elevated antibody titers against human herpesvirus-6 (HHV-6) and Epstein-Bar virus (EBV) who were experiencing central nervous system dysfunction including longstanding fatigue. J Clin Virol 2006:37 Suppl 1:S33-8.

12 Costigan A, Elliott C, McDonald C, et al. Orthostatic symptoms predict functional capacity in chronic fatigue syndrome: implications for management. QJM 2010;103:589-95.

13 Strayer DR, Carter WA, Stouch BC, et al. A double-blind, placebo-controlled, randomized, clinical trial of the TLR-3 agonist rintatolimod in severe cases of chronic fatigue syndrome. PLoS One 2012;7:e31334.

14 Johnson C. Norwegian rituximab chronic fatigue syndrome (ME/CFS) trial fails. Simmaron Res, 2017. Available: http://simmaronresearch.com/2017/11/norwegianrituximab-chronic-fatigue-syndrome-mecfs-trial-fails/ [Accessed 10 Aug 2018].

15 Collatz A, Johnston SC, Staines DR, et al. A systematic review of drug therapies for chronic fatigue Syndrome/Myalgic encephalomyelitis. Clin Ther 2016:38:1263-71.

16 Bolton M, Hodkinson A, Boda S, et al. Serious adverse events reported in placebo randomised controlled trials of oral naltrexone: a systematic review and meta-analysis. BMC Med 2019;17:1-13

17 Yi Z, Guo S, Hu X, et al. Functional modulation on macrophage by low dose naltrexone (LDN). Int Immunopharmacol 2016:39:397-402.

18 McLaughlin PJ, Zagon IS. Duration of opioid receptor blockade determines biotherapeutic response. Biochem Pharmacol 2015:97:236-46.

19 Liu WM, Scott KA, Dennis JL, et al. Naltrexone at low doses upregulates a unique gene expression not seen with normal doses: implications for its use in cancer therapy. Int J Oncol 2016;49:793-802.

20 Toljan K, Vrooman B, Naltrexone L-D. Low-Dose Naltrexone (LDN)-review of therapeutic utilization. Med Sci 2018;6:82

21 Cree BAC, Kornyeyeva E, Goodin DS. Pilot trial of low-dose naltrexone and quality of life in multiple sclerosis. Ann Neurol 2010;68:145-50.

22 Sharafaddinzadeh N, Moghtaderi A, Kashipazha D, et al. The effect of low-dose naltrexone on quality of life of patients with multiple sclerosis: a randomized placebocontrolled trial. Mult Scler 2010;16:964-9.

23 Brewer KL, Mainhart A, Meggs WJ. Double-Blinded placebo-controlled cross-over pilo trial of naltrexone to treat Gulf War illness. Fatigue: Biomedicine, Health \& Behavior 2018:6:132-40.

24 Traore AK, Thiero O, Dao S, et al. Impact of low dose naltrexone (LDN) on antiretrovira therapy (ART) treated HIV + adults in Mali : a single blind randomized clinical trial. J AIDS HIV Res 2011;3:189-98.

25 Smith JP, Bingaman SI, Ruggiero F, et al. Therapy with the opioid antagonist naltrexone promotes mucosal healing in active Crohn's disease: a randomized placebo-controlled trial. Dig Dis Sci 2011;56:2088-97. 
26 Smith JP, Field D, Bingaman SI, et al. Safety and Tolerability of Low-dose Naltrexone Therapy in Children With Moderate to Severe Crohn's Disease. J Clin Gastroenterol 2013;47:339-45.

27 Younger J, Noor N, McCue R, et al. Low-Dose naltrexone for the treatment of fibromyalgia: findings of a small, randomized, double-blind, placebo-controlled, counterbalanced, crossover trial assessing daily pain levels. Arthritis Rheum 2013;65:529-38.

28 Abou-Raya S, Abou-Raya A, Khadrawi T. SAT0402 Efficacy of Naltrexone in the Treatment of Fibromyalgia: Randomized Controlled Trial. Ann Rheum Dis 2013;72:A719.

29 Raknes G, Simonsen P, Småbrekke L. The effect of low-dose naltrexone on medication in inflammatory bowel disease: a Quasi experimental before-and-after prescription database study. J Crohns Colitis 2018;12:677-86.

30 Raknes G, Småbrekke L. Low dose naltrexone: effects on medication in rheumatoid and seropositive arthritis. A nationwide register-based controlled quasi-experimental before-after study. PLoS One 2019;14:e0212460.

31 Wouk J. LDN World Database - CFS/ME, 2019. Available: http://www.Idndatabase. com/cfs.html [Accessed 7 May 2019].

32 Kennedy Get al. The specificity of the C D C-1994 criteria for chronic fatigue syndrome: comparison of health status in three groups of patients who fulfill the criteria. Ann Epidemiol 2004;14:95-100.

33 Stroop JR. Studies of interference in serial verbal reactions. J Exp Psychol 1935;18:643-62.

34 Tombaugh TN. Trail making test a and B: normative data stratified by age and education. Arch Clin Neuropsychol 2004;19:203-14.

35 Fastenau PS, Denburg NL, Hufford BJ. Adult norms for the Rey-Osterrieth complex figure test and for supplemental recognition and matching trials from the extended complex figure test. Clin Neuropsychol 1999;13:30-47.
36 Carruthers BM, van de Sande MI, De Meirleir KL, et al. Myalgic encephalomyelitis: international consensus criteria. J Intern Med 2011;270:327-38.

37 Zigmond AS, Snaith RP. The hospital anxiety and depression scale. Acta Psychiatr Scand 1983;67:361-70.

38 Moss J. Development of a functional ability scale for children and young people with myalgic encephalopathy (ME)/chronic fatigue syndrome (CFS). J Child Health Care 2005;9:20-30.

39 Ludwig MD, Zagon IS, McLaughlin PJ. Featured article: modulation of the OGF-OGFr pathway alters cytokine profiles in experimental autoimmune encephalomyelitis and multiple sclerosis. Exp Biol Med 2018;243:361-9.

40 Cant R, Dalgleish AG, Allen RL. Naltrexone inhibits IL-6 and TNF $\alpha$ production in human immune cell subsets following stimulation with ligands for intracellular Tolllike receptors. Front Immunol 2017;8:809.

41 Hutchinson MR, Bland ST, Johnson KW, et al. Opioid-Induced glial activation: mechanisms of activation and implications for opioid analgesia, dependence, and reward. ScientificWorldJournal 2007;7:98-111.

42 LDN Research Trust conference. Dr. Tom Gilhooly - YouTube, 2013. Available: https:// www.youtube.com/watch?v=G6SWv7HEj8M [Accessed 27 Mar 2019].

43 Fluge Øystein, Rekeland IG, Lien K, et al. B-Lymphocyte depletion in patients with myalgic Encephalomyelitis/Chronic fatigue syndrome: a randomized, double-blind placebo-controlled trial. Ann Intern Med 2019;170:585-93.

44 Dickson S. Low dose naltrexone 2018 information pack, 2018. Available: https:// www.Idnresearchtrust.org/sites/default/files/LDN-2018-Fact Sheet-UK-Europe.pdf [Accessed 3 May 2019].

45 VanElzakker MB, Brumfield SA, Lara Mejia PS. Neuroinflammation and cytokines in myalgic Encephalomyelitis/Chronic fatigue syndrome (ME/CFS): a critical review of research methods. Front Neurol 2018;9:1033.

Copyright 2020 BMJ Publishing Group. All rights reserved. For permission to reuse any of this content visit https://www.bmj.com/company/products-services/rights-and-licensing/permissions/ BMJ Case Report Fellows may re-use this article for personal use and teaching without any further permission.

Become a Fellow of BMJ Case Reports today and you can:

- Submit as many cases as you like

- Enjoy fast sympathetic peer review and rapid publication of accepted articles

- Access all the published articles

- Re-use any of the published material for personal use and teaching without further permission

Customer Service

If you have any further queries about your subscription, please contact our customer services team on +44 (0) 2071111105 or via email at support@bmj.com. Visit casereports.bmj.com for more articles like this and to become a Fellow 